\title{
Çalışma Yaşamında İkiz Rakip Üretimi: Kadının Kadına Engeli ${ }^{1}$
}

\section{Production of Twin Rival in Working Life: Woman's Hindrance to Woman}

\author{
E. Sahra Öztürk ${ }^{2}$
}

\section{Öz}

Kapitalist düzende kadın, içine itilmiş olduğu rekabet ortamında savaş vermeyi amaç edinerek öncelikle kendine ve ailesine yabancılaşmaktadır. Kadın, bireysel ve toplumsal vasıfları doğrultusunda çalışma yaşamında vandal rekabet koşullarında mücadele vermektedir. Çalışma yaşamındaki sorunlar, kadının aile yapısındaki önemli etkisi ve buna bağlı sorumlulukları doğrultusunda aileye katkılarını da sekteye uğratmaktadır. Bu doğrultuda çalışma, mevcut ve önemli sorunlardan biri olan çalışma yaşamında ikiz rakip üretimi kavramını öne sürerek kadının kadına olan engelini sunmaktadır.

Anahtar Kelimeler: Çalışma yaşamı-Kadın ve Aile, Mobbing, İkiz Rakip Üretimi

\section{Abstract}

In the capitalist system, women who have found themselves fighting in a battle field filled with competition, firstly alienate themselves and their families. Women have to struggle in the harsh conditions of adversarial competition. The problems in the workplace interrupt women's contributions to the family in parallel with their crucial

1 Bu makale, 7 Mart 2017 tarihinde "III. Uluslararası Toplumsal Cinsiyet Adaleti: Kadın ve Aile" kongresinde bildiri olarak sunulmuştur.

2 Yeditepe Üniversitesi, Sosyal Bilimler Enstitüsü Medya Çalışmaları Doktora Adayı, orcid.org/0000-0001$5202-7270$ 
effects on family structureand related responsibilities. Accordingly, this study puts forward the production of twin adversaries in work life within the scope of women's hindrance of other women.

Keywords: Work life-Women and Family, Mobbing, Production of Twin Rival

\section{Giriş}

Kapitalist düzende ve buna bağlı küreselleşen toplumda kadın, içine itilmiş olduğu rekabet ortamında savaş vermeyi amaç edinerek öncelikle kendine ve ailesine yabancılaşmaktadır. Kadın, bireysel ve toplumsal vasıfları doğrultusunda çalışma yaşamında maskülenleşerek vandal rekabet koşullarında mücadele vermektedir. Bu mücadele süresince kadın kendini ve ailesini göz ardı ederek iş yaşamını, merkezine almaya itilmektedir. Fakat toplumda ikincil bir konumlandırma sıfatı taşıyan kadının mücadelesi, aile gereksinimlerindeki önemi ve buna bağlı sorumlulukları doğrultusunda aile yapısındaki katkılarını da sekteye uğratmaktadır. Bunlara karşın kadının iş yaşamından uzak tutulma düşüncesinin olmaması ve olmayacağı gerektiği gibi bu zorlu hayatta kalma savaşında gerek kadın dernekleri gerek iş yaşamı odaklı sivil toplum kuruluşlarının ve devlet çalışmaları kapsamında kadının haklarını korumaya yönelik uygulamalar yapılmakta, mevcut ve olası sorunlara çözümler aranmaktadır. ${ }^{3} \mathrm{Bu}$ doğrultuda bu çalışma, mevcut ve önemli sorunlardan biri olan çalışma yaşamında kadının kadına olan engeli kapsamında ikiz rakip üretimini açıklamayı amaçlamaktadır.

Günümüzde bilindiği üzere mobbing kavramı sadece ülkemizde değil dünyada hem bireye hem ailesine hem de çevresine psikolojik hasarlar verdiği suçlardan biri olarak kabul edilmektedir. İş yerinde psikolojik taciz olarak ifade edilen mobbing, çalışanların birbirlerini rahatsız ve huzursuz edici davranışlarla taciz etmeleri, kötü davranmaları, diğer bir deyişle psikolojik şiddet uygulamaları anlamında kavramlaştırılmaktadır (Leymann, 1996, s. 167-168). Bir kişinin veya kişilerin, bir kişiye veya kişilere karşı düşmanlığı biçiminde gelişen örgütsel psikolojik şiddet olan mobbingde mağdur zamanla kendini tanımamaya başlayarak dayatılan çalışma yaşamını kanıksamakta ve öncelikle kendini sonra da çevresini yıpratabilmektedir. Zamanla mağdur kişide, iş yerinde üstleri tarafından korunmadığı hissi gelişerek, kendisine ifade hakkı verilmediğinden kaynaklı iş yerine güvensizlik, gelecek kaygısı, yılgınlık, bıkkınlık, performans düşüklüğü vb. duygular oluşmakta ve durum mağdurun istifası ile sonlanmaktadır (Einersen vd. 2003, s. 4-15).

Mobbing anlaşılacağı üzere hem kadın hem erkek tarafından gerçekleştirilebilir bir olgu olmakla birlikte bu çalışmada kadının kadına uyguladığı mobbinge dikkat çekil-

3 http://www. csgb. gov. tr/media/3417/proje_2015. pdf 
mektedir. Çalışma, mobbing kapsamında ikiz rakip üretimi kavramını ortaya atmakla birlikte çalışma yaşamında kadının kadına karşı ikiz rakip üretiminin daha baskın olduğu hipotezini içermektedir. Çalışmada nitel ve nicel araştırma yöntemleri kullanılmakla birlikte mobbing kavramı ile ikincil kaynak oluşturan literatür taraması yapılmış, vaka çalışmaları incelenmiştir ve hipotezin test edilmesi için çalışmada gözlem ve anket tekniği kullanılmış olup birincil kaynak sağlanmıştır. Buna bağlı olarak, İstanbul'da yer alan özel sektör, yarı özel- yarı kamu ve kamu kuruluşlarından birer örneklem seçilmiş, hem erkek hem kadın çalışanlar üzerinde anket uygulanmıştır. Çalışmanın hipotezi doğrultusunda; mobbing kapsamında ikiz rakip üretimi gerçekleşiyor mu? ikiz rakip üretimi mobbingin üç farklı işleyişi olan üstün asta- yatay ve astın üste uyguladığı mobbinglerden en çok hangisinde gerçekleşmektedir? ikiz rakip üretimi daha çok kıdemli çalışanlar tarafından $\mathrm{m}$ gerçekleştiriliyor? çalışma yaşamında kadın, kadına engel oluyor mu? soruları oluşturulmuştur. Çıkan sonuçlar neticesinde hipotezin geçerliliği analiz edilmiş ve kurumların (özel, yarı özel- yarı kamu ve kamu) yapılarına göre değişken sonuçlar olabileceği varsayımında bulundurulmuş olup öneriler sunulmuştur.

\section{Kadın - Çalışma Yaşamı ve Aile}

Ekonomik kalkınmışlı̆̆ın gereği kabul edilen kadının çalışma yaşamına katılması diğer bir deyişle iktisadi hayata kazandırılması, ülke için bir kazanç olmakla birlikte kalkınmayı hızlandırması açısından önem arz etmektedir. Bu amaçla günümüz kapitalist ekonomik sistemin koşulları doğrultusunda kadın, çalışma yaşamına katılımı ile ekonomik büyümeye katkı sağlarken aynı zamanda dayatılan rekabet ortamında sağladığı katkıdan daha büyük bir mücadele vermektedir. Türkiye’de kadınların, emek piyasası olarak da tabir edilen çalışma yaşamı ile tanışması 1912-13 Balkan Savaşları sırasında erkeklerin orduya katılımları sebebiyle azalan iş gücüne takviye sağlanması amacıyla gerçekleşmiş olup I. Dünya, İstiklal ve II. Dünya Savaşları ile birlikte giderek artmıştır (Berber ve Eser, 2008, s. 3).

Cumhuriyet sonrası yaşanan kırdan kente göç, sanayileşme, kadınlara tanınan sosyal, hukuki, siyasal haklar kadının toplumdaki konumunu ve çalışma şekillerini değiştirmeye başlamıştır. Kadının çalışma yaşamına girmesi, sosyal ve ekonomik alanlarda köklü değişimleri meydana getirmiştir. Toplumda ikincil konum ile özdeşleştirilen kadın, çalışma yaşamında öncelikli olarak tarımda, sanayileşme sonrasında da çırak, yamak vb. olarak düşük ücretlerle çalıştırılmaya mahkum edilmiştir. Kadın iş gücü, eril ekonomik örgütlenme içerisinde erkek işgücünün ikamesi olarak ikincil bir konuma indirgenmiştir. Diğer bir deyişle, kadın eril ekonomik çalışma yaşamındadaha düşük ücretlerle erkeğin eksik veya yetersiz kaldığı zamanlardaki boşlukları doldurmak ve ekonomik sürdürebilirliği devam ettirmek amacıyla erkeğin yedeği olarak konumlandırılmıştır.

Halbuki büyük ölçüde erkeğin eve gelir getirdiği toplumsal yaşam biçimimizde ekonomide gerçekleşen krizler nedeniyle bu durum sekteye uğrayabilmekte ve zor ko- 
şullara gögüs gerecek olan kadının sadece yedek olarak değil tam anlamıyla çalışma yaşamına katılımı tetiklenmektedir. Bu durum sadece ekonomik krizlerle minimalize edilmeyecek olup aynı zamanda iş kazaları, hastalık, ölüm vb. nedenlerden ötürü de erkeğe bağlı tek kazanımlı aile modeli yoksulluk ile mücadele etmeye mahkum kalmaktadır. Bu bağlamda, eril ekonomik örgütlenmede erkeklerin de işsiz kalma risklerine karşılık kadının çalışma yaşamına katılımının artması ve çift kazanımlı hane modeli teşvik edilmektedir. Böylece önemi teslim edilmeyen, ev içi sorumlukların yanı sıra çalışma hayatının sorumluluklarını da yüklenen kadın, çalışma hayatında karşılaştığı zorluklara karşı da farklı bir mücadeleye girmektedir. Hem iktisadi hem de toplumsal yaşamın bir bütün olarak değiştiği bu durumda kadının yaşamı, ev ve iş yerinden oluşan iki ayrı dünya kapsamında yeniden şekillenmektedir.

Bu bağlamda ülkemizde kadının siyasi ve toplumsal hayattaki konumunun güçlendirilmesine yönelik ilk çalışmalar Cumhuriyetin kuruluş yıllarından itibaren uygulanmaya başlanmıştır. Yasal düzenlemeler kapsamında; 1998 yılında yürürlüğe giren “4320 sayılı Ailenin Korunmasına Dair Kanun” aile içindeki şiddete karşı önlem alırken, evli kadının çalışması ile ilgili olarak ise Medeni Kanun'un 192. maddesinde "eşlerden hiçbiri iş veya meslek seçimi konusunda diğerinin iznini almak zorunda değildir" ibaresi esas alınmıştır. ${ }^{4}$ Öte yandan ülkemizde kanayan bir yara olan kadına şiddet olaylarının önlenmesine yönelik çalışmalar yapılmış olup, iyileştirme odaklı çabalar devam etmektedir. Ayrıca son yıllarda kadının çalışma yaşamını yapılandırıcı kararlar da alınmaktadır. 24. 07. 2013 tarihinde yayınlanan "Kadın Çalışanların Gece Postalarında Çalıştırılma Koşulları Hakkında Yönetmelik” uygulamaya alınan önemli düzenlemelerdendir. Bununla beraber 4857 sayılı İş Kanunu ile kadın işçilere annelik ve emzirme durumunda tanınan haklar konusunda ilerleme sağlanmıştır. Günümüzde kadının çalışma yaşamındaki mevcut durumlarını iyileştirmeye yönelik kararlar alınırken aynı zamanda İŞKUR (İş ve İşçi Bulma Kurumu) ve ilgili kuruluşlar da kadın istihdamının arttırılması, kadının mesleki beceri kazanması ve işe yönlendirilmesi için çalışmalarını sürdürmektedir. Bu çalışmalar ile birlikte TÜİK (Türkiye İstatistik Kurumu, 2016) verilerine göre, kadınların iş gücüne katılma oranının son on yılda önemli bir artış kaydederek 2015 yılında \%30. 3 olduğu görülmektedir.

Kadın istihdam teşvikleri bir yandan ekonomik kalkınmayı ve temel eşitlik haklarını artırmayı hedeflerken diğer yandan kadının içine itilmiş olduğu rekabet ortamında savaş vermesini amaç edindirerek öncelikle kendine ve ailesine yabancılaşmasına da sebep olmaktadır. Bu bağlamda kadın, çalışma yaşamında maskülenleşerek vandal rekabet koşullarında karşı cins ile mücadele etmektedir. Birçok yönetim kademesinde erkeklerin mevcudiyeti ve toplumsal üretime dahil olan kadınların emek gücünün erkeklere oranla ucuza kiralanmakta olması bu durumu özetlemektedir. Bu sebeple kadın, çalışma yaşamı süresince gerek yönetim gerek çalışma arkadaşları tarafından oluşturulan zorluklara da maruz kalmaktadır.

4 http://www. mfa. gov. tr/turkiye_de-kadin-haklari-alaninda-kaydedilen-gelismeler. tr. mfa 


\section{Mobbing}

Ev ve iş yeri arasında mücadele veren kadının çalışma yaşamında karşılaştığı en büyük zorluk ve sonucunda hasar gördüğü etken "mobbing"dir, diğer bir ifadeyle iş yerinde karşılaştığı psikolojik tacizdir. Çalışma yaşamında görülen ve bir çeşit psikolojik terör olan mobbing her iki cinsi, hem kadını hem de erkeği kapsadığından sadece kadına indirgenmemektedir. Fakat diğer yandan kadının ev yaşamındaki anaç ve hassas karakteri ile sorumlulukları göz önüne alındığında, mobbingin kadın üzerindeki etkisinin daha ağır olduğu görülmektedir.

Mobbing’in özellikle son yıllarda literatürde çeşitli tanımları yapılmakla birlikte, ilk olarak 1960’lı yıllarda hayvan davranışlarını inceleyen Kontranz Lorenz tarafından büyük bir hayvanın tehdidine karşı daha küçük hayvan gruplarından gelen karşı saldırıları ifade etmek amacıyla kullanılmıştır (Yücetürk, 2002). Mobbing, çalışanların birbirlerini rahatsız ve huzursuz edici davranışlarla taciz etmeleri, kötü davranmaları, diğer bir deyişle psikolojik şiddet uygulamaları anlamında kavramlaştırılmaktadır (Leymann, 1996, s. 167-168). İlk kez 80’li yıllarda Alman çalışma psikoloğu Heinz Leymann'ın ${ }^{5}$ kavramsallaştırdığı mobbingde faillerin diğer bir deyişle uygulayıcıların büyük çoğunluğu kendisini iyi bir lider olarak tanımlamakta ve mobbing yaptığını kabul etmemektedir. Davenport vd. (2003, s. 15) göre mobbing, kişinin diğer kişileri kendi rızaları veya rızaları olmadan dahil ederek başka bir kişiye karşı sürekli kötü niyetli hareketlerde bulunma, alay, ima ve kişinin itibarını düşürme gibi yollarla rahatsız bir ortam yaratarak kişiyi işten çıkmaya zorlamaktır. Bir kişinin veya kişilerin, bir kişiye veya kişilere karşı düşmanlığı biçiminde gelişen örgütsel psikolojik şiddet olan mobbingde mağdur zamanla kendini tanımamaya başlayarak dayatılan çalışma yaşamını kanıksamakta ve öncelikle kendini sonra da çevresini yıpratabilmektedir. Zamanla mağdur kişide, yapılan psikolojik şiddet ile birlikte iş yerinin kendini korumadığı, kendine ifade hakkı verilmediğinden kaynaklı iş yerine güvensizlik, gelecek kaygısı, yılgınlık, bıkkınlık, performans düşüklügü vb. durumlar oluşmakta ve mağdurun istifa etmesiyle sonlanmaktadır (Einersen, vd. 2003, s. 4-15). DiMartino vd. (2003) göre ekonomik küreselleşmenin neticesinde pazar payı kapma yarışının çalışanlar üzerindeki psikolojik baskıyı artırmasının mobbing durumuna yol açan en önemli nedenlerden biri olduğu ifade edilmektedir. Field (2002, s. 878-830), mobbingin nedenlerini araştırmış olup, mobbingin eksik ve yetersiz yönetimlerde dikkatli olunmadığından çalışanlar arasındaki moralsizliğin artması, örgütsel sağlığın azalması, zaman ve enerjinin ekonomik şekilde kullanılmaması, çalışanların işyerinden soğuması ve soğutulması ve sürekli çatışmaların olması sonucu oluşan kötü örgüt atmosferinde ortaya çıktığını ifade etmektedir. Hoel ve Cooper (2000, s. 20) ise mobbinge neden olan yönetim tarzlarının karakteristik özellikleri üzerine yaptıkları araştırmalarında, otokratik yönetim tarzı, anlaşmazlık yaratan yönetim tarzı, umursamaz yönetim tarzı ve cezalandırıcı yönetim tarzını benimsemiş yapılarda mobbingin oluştuğunu belirtmektedirler. Archer'a (1999, s. 95) göre, mobbing daha çok askeri, sağlık vb. aşırı hiyerarşik yapılı, köklü kültüre ve geleneğe sahip örgütlerde görülmektedir.

5 http://www. psychologicalharassment. com/Professor-Heinz-Leymann-Biography. htm 
Mobbingin yukarıdan aşağıya, yatay ve aşağıdan yukarıya uygulanan üç farklı işleyişi bulunmaktadır. Birinci işleyiş olan yukarıdan aşağıya, üstün astına olan mobingi; ikinci olan yatay işleyiş aynı statüdeki personelin birbirine olan mobingi; üçüncü ve son olan aşağıdan yukarıya uygulanan işleyiş de astın üste olan mobingi ifade etmektedir (Tınaz, 2006, s. 116). Mobbing failleri ve mağdurlarının kişilik özelliklerine dair yapılan bir araştırmada; mağdurların kişilik özellikleri savunmasız oluşları, başarılı ve grup normlarına uymamaları şeklinde tanımlanırken, mobbing faillerinin temel kişilik özellikleri ise özgüvenleri yüksek, sosyal becerileri az ve küçük çıkarlar için politik oyunlara açık karakterde oldukları ifade edilmektedir (Zapf ve Einarsen, 2003, s. 165-184). Dünya Sağlık Örgütü’ün (WHO, 2003, s. 15) çalışmasında; sağlıklı çalışma ortamı ile mobbing arasındaki farklılıklar araştırılmış olup; sağlıklı çalışma ortamında rollerin, iş tanımlarının açık ve işbirliğinin sağlandığı, iletişimin sağlıklı olduğu ifade edilirken, mobbing ortamında ise rollerin belirsiz oluşu, örgütsel eksikliklerin var oluşu ile birlikte işbirliğin sağlanamadığına dikkat çekilmektedir. Psikoloji bilimi kapsamında, mobbing uygulayanlar diğer bir deyişle psikolojik taciz failleri, ilgi açlı̆̆ çeken, övgüye ihtiyaç duyan, çalışma ortamında kendini yetersiz hisseden, sosyal beceri eksikliği olan kişiler olarak ifade edilmektedir (Kök, 2006, s. 436-438). Ekonomik perspektiften bakıldığında ise rekabet ortamında mobbing yapan bu kişiler (üstten asta uygulanan mobbing doğrultusunda) mevcut statülerini daha doğrusu maaşlarını korumayı veya (yatay ve aşağıdan üste uygulanan mobbing doğrultusunda) daha yüksek maaşlara erişme arzusunu gerçekleştirmeyi hedeflemektedirler.

Dünyanın birçok yerinde mobbingin çalışma yaşamına ve bireylere zarar vermekte olduğu görülmektedir. Avrupa Birliği’ne üye olan ülkelerde gerçekleştirilmiş araştırma sonucuna göre en az 12 milyon kişinin mobbinge maruz kaldığ 1 görülmüş olup, bu sonuçlara göre İngiltere’de \%16, İsveç'te \%10, Fransa ve Finlandiya'da \%9, İrlanda ve Almanya'da \%8, Belçika, Yunanistan ve İspanya'da \%5, İtalya'da \%4 olarak saptanmıştır (Espresso, 2000, s. 64). Türkiye'de ise mobbingin en çok 29-33 yaş aralığında gözlendiği, kadınların erkeklere göre daha fazla psikolojik baskıya maruz kaldığı, en sık karşılaşılan mobbing türünün ise yönetici tarafından anlamsız veya yeteneğin altında görevler verilmek yoluyla ortaya çıktığı görülmektedir (Dural, 2016, s. 6-10). Ülkemizde hukuksal boyutta mobbing ile ilgili olarak; 11. 01. 2011 tarihinde kabul edilen ve 04. 02. 2011 tarihli 27836 sayılı Resmi Gazetede yayımlanan 6098 sayılı Borçlar Yasası'nın 417. maddesinde ilk kez psikolojik taciz kavramı kullanılmış olmakla beraber bu yönde çalışmalar devam etmektedir. Mobbing failine yasal ceza verilmesi hususu ise, hukuki olarak en önemli unsur olan mağdurun faillerin mobbingi uyguladıklarına dair yeterli delilinin olamayışından, çalışma ortamındaki şahitlerin bu tür hukuki sürece katılmak istememelerinden ötürü bir neticeye varamamaktadır. Hukuki süreçlerde nasıl yol alınacağını öğrenmek adına Çalışma ve Sosyal Güvenlik Bakanlığı’nın İletişim Merkezi "Alo 170” mobbing mağdurları için önemli bir hizmet sağlamaktadır. 2013yılına göre "Alo 170" hattını iki sene içerisinde 5.890 kişi aramış olmakla beraber; hattı arayanların \%20'sinin istifaya zorlandığı, mağdurların \%87’nin 
mobbing faillerinin amirleri olduğu, başvuruların \%67’si özel sektör ve \%33’ü kamu olduğu ve kadınların daha fazla mobbing mağduru olduğu tespit edilmiştir. ${ }^{6}$

\section{İkiz Rakip Üretimi}

Anlaşılacağı üzere sistemli bir şekilde yapılan, süreklilik kazanmış, sıklıkla tekrarlanan ve hatta bazı kurumlarda gelenekselleşmiş olan mobbing, tüm ülkelerde ve kültürlerde yaş, cinsiyet gözetmeden uygulanabilmektedir. Ülkemizde de son yıllarda mobbing kavramı yaygınlaşmış olup mağdurun kendini ve dayatılan psikolojik tacizdeki farkındalığının arttığı gözlemlenmektedir. Fakat yapılan çalışmalarda ağırlıklı olarak mobbingin ne şekilde mağdura yansıdığı, mağdurun fiziksel, sözel, dışlanma vb. nasıl bir muamele ile karşılaştığı araştırılırken, mobbing failinin zaman, koşul ve çevresiyle bağlantılı olarak kendini yenileyen dinamik süreçleri doğrultusunda nasıl bir mobbing çeşidi belirlediği göz ardı edilmektedir. Bunun sebebi ise mobbing mağdurunun psikolojik çöküntüyle birlikte içinde sıkışmış olduğu baskılardan ötürü mobbing failinin nasıl bir taktik geliştirdiğinin farkına varamamasıdır. Farkına varamadığından ötürü de olay çalışmalarına örnek teşkil edememekte ve derinlemesine araştırılamamaktadır. Bu doğrultuda bu çalışma mobbing failinin uyguladığı bir sürece açıklık getirmekte olup ikiz rakip üretimi kavramını ortaya atmaktadır. Bu kapsamda ikiz rakip üretimi, mobbing sürecinde düşman belirlenen hedefi yıldırmak ve oyun dışı etmek amacıyla mağdurun vasıflarına yakın, benzer veya benzetilen mobinge dahil olan veya olacak, kurum içi veya kurum dışından alınan personel ile gerçekleştirilmektedir. Bu doğrultuda üretilen rakip, mağduru taklit ederek yerine geçmekte, aynı işleri yapmaya veya yapıyor gibi gösterilmektedir. Böylece kurum yönetimine ve diğer personellere mobbing mağduru unutturulmakta, onsuz da bir şekilde işlerin devam ettiği portresi çizilmektedir ve ilerleyen zamanlarda üretilen rakibin adaptasyonunun tamamlanmasıyla birlikte işler bir şekilde devam ettirilebilmektedir.

İkiz rakip üretimi, mobbing sürecinde fail tarafindan ve örgütlü olarak gerçekleştirilmektedir. Çünkü bu süreçte mobbing faili, bu örgütsel eylemini gerçekleştirmek amacıyla anlaşabildiği ve çalışma yaşamında kontrolü altında tutabildiği kişiyi kendi planına dahil etmektedir. Bu bağlamda mobbing faili, kendine çalışma yaşamında rakip olmayacağını düşündüğü ve bir benzer oluşturmak istediği kişiyi, gözlem sürecinde tuttuğu, birlikte çalışmak istemediği mağdura karşı rakip olarak eğitme tutumuna girmektedir. Bu durumda rakip olarak seçilen kişi, mağdura yapılan eylemin farkında olabileceği gibi aynı zamanda farkında olamaya bilmektedir. Bu bağlamda mobbing faili üretmek istediği rakibini, mağdur hakkında iftira, karalama vs. ile kandırma yolu ile kendi örgütsel eylemine dahil ederek veya üreteceği rakibe direkt neden mağduru istemediğini açıkça dile getirerek mobbing sürecine devam edebilmektedir. Mobbing faili bu hususta mağdura yaptıkları ve yapacakları ile ilgili üreteceğe rakibe, mağduru ezme ve dişlama düşüncelerini açıklamak yerine, onu mağdura karşı olumsuz fikirlerle yönlendirme yoluna gitmesi kendi lehine hem kolay hem de avantajlı olmaktadır. Böylece ürettiği rakibin kontrolünü sağlayabilmekte ve niyetini açık etmeden hak-

6 http:www. ntv. com. tr/ekonomi/turkiyenin-mobbing-karnesi, 8B9nQH_8zkKZbbhjfUI0Ag 
lı olduğu algısını oluşturabilmektedir. Planlanan ve uygulamaya sokulan ikiz rakip üretimi eylemi, mağdurun istifası veya yönetime mağdurun çalışma arkadaşlarıyla geçimsiz olduğu vs. benzer karalamalarla birlikte işlerini yapan, yerini dolduran personellerin olduğu aktarılarak artık ona ihtiyaç duyulmasına gerek kalmadığı bilincinin yerleştirilmesiyle amaca ulaşmaktadır.

İkiz rakip üretimi görüldüğü üzere tek bir cinse indirgenmemekle birlikte hem kadını hem erkeği kapsamaktadır. Bu süreç, mobbingin üsten asta, astın üste ve yatay olmak üzere üç farklı işleyişinde de görülebilmektedir. Üst, astlardan birinin gerek eğitim gerek beceri vs. sebeplerden ötürü kendisini yerinden edeceği korkusuyla; ast, üstünün baskıcı tavırlarından, mevkisini kıskanmasından vs. sebeplerden ötürü yerine geçme isteyişinden; yatay olarak ise aynı statüdeki personellerden birinin daha takdir görmesi veya bir adım önüne geçme ihtimali vs. sebeplerinden ötürü ikiz rakip üretimi geliştirilebilmektedir. Buradaki önemli nokta ve gerçekleştirilen amaç hangi statüden olursa olsun istenmeyen hedefin yerine bir rakip üretilmesidir.

\section{Şema: İkiz Rakip Üretimi’nde Nedenler ve Kullanılan Yollar}

\begin{tabular}{|c|c|c|}
\hline \multicolumn{2}{|c|}{ Nedenler } & $\begin{array}{l}\text { İkiz Rakip Üretimi'nde } \\
\text { Kullanılan Yollar }\end{array}$ \\
\hline $\begin{array}{l}\text { Üstün Asta Olan } \\
\text { Nedeni }\end{array}$ & Mevkiyi kaybetme korkusu & $\begin{array}{l}\text { * Üretilen rakibi teşvik etmek } \\
\text { * Mağdura pasifize olacak işler } \\
\text { vermek } \\
\text { * Mağduru dışlamak } \\
\text { * Mağdurun işlerini üretilen rakibe } \\
\text { devretmek } \\
\text { * Mağdura hatalar yaptırtılırken } \\
\text { üretilen rakibin başarısını takdir } \\
\text { etmek } \\
\text { * Mağdurda kusurlar bulmak }\end{array}$ \\
\hline Astın Üste Olan Nedeni & $\begin{array}{l}\text { * Üstün baskıcı yapısı } \\
\text { ^Astın mevkiye erişme } \\
\text { çabası }\end{array}$ & $\begin{array}{l}\text { * Üretilen rakibi teşvik etmek veya } \\
\text { kendini ikiz rakip olarak üretmek } \\
\text { • Üstün doğru kararlar vermediğini } \\
\text { göstermek }\end{array}$ \\
\hline Yatay Neden & $\begin{array}{l}\text { Diğer personelin gerisinde } \\
\text { kalacağı endişesi }\end{array}$ & $\begin{array}{l}\text { * Kendini ikiz rakip olarak üretmek } \\
\text { * Diğer personelde hatalar göstermek } \\
\text { * Kendisini ön plana çıkarmak ve } \\
\text { üstün olduğunu göstermek } \\
{ }^{*} \text { Diğer personeli üste şikayet etmek }\end{array}$ \\
\hline
\end{tabular}


Şemada görüldüğü üzere ikiz rakip üretiminde üstün asta olan nedeni mevkiyi kaybetme korkusudur. Bu korku, kendi konumunu sarsacağını düşündügü personelin iyi eğitimli, tecrübeli, becerikli vb. vasıflara sahip oluşundan kaynaklanmaktadır. Kullandığı yollar ise; ürettiği rakibini mağdura benzer şekilde eğitmek, motive etmek ve taklit etmesini teşvik etmek, mağduru gerek ekip çalışmalarında gerek öğle molalarında dışlayarak yalnız kalmasını sağlamak, mağdurun işlerini üretilen rakibe devretmek, mağdura hatalar yaptırılırken üretilen rakibin başarısını takdir etmek, mağdurda kusurlar bulmaktır. Astın üste olan ikiz rakip üretiminde ise iki neden gösterilmektedir. Birincisi üstün baskıcı yapıda olması, ikincisi ise astın üstünün mevkisine erişme eğiliminde olmasıdır. Kullanılan yollar; eğer üstün mevkisine erişmesindeki basamak aralığı fazla ise amir olabilecek bir rakibi teşvik etmek, eğer kendini üst olarak aday göstermekte ise kendini rakip olarak üretmektir. Her iki koşulda da ast, üstün hatalarını ortaya çıkarmaktadır. Yatay ikiz rakip üretimindeki neden ise aynı statüdeki personellerden birinin eğitim, beceri, sevilen karaktere sahip oluşu vb. sebeplerden ötürü diğer çalışana kıskançlık duyarak onun gerisinde kalacağı endişesidir. Bu durumda kişi, hedefindeki çalışma arkadaşına karşı kendini ikiz rakip olarak üretmekte; terfi alacağını düşündüğü çalışma arkadaşını taklit ederek kendisini ön plana çıkarmakta, kendisinin üstün olduğunu göstermekte ve devamlı üstüne o kişiyi şikayet etmektedir.

Dünya genelinde ve ülkemizde tüm eğitim düzeylerinde erkeklerden daha düşük ücret alan, hane halkı ve aile bakımı faaliyetlerine erkeklerden daha fazla zaman ayıran kadınlar açısından ikiz rakip üretimi kavramına bakıldığında, durum daha ciddi bir probleme işaret etmektedir. Çünkü çalışma yaşamında erkeklere göre azınlıkta olan kadının, çalışma arkadaşı olan bir kadına bu tip bir eylem sürecinde bulunarak kendi cinsini ötekileştirmesi ve çalışma yaşamından uzaklaşmasına neden olması vahim bir gerçektir. Bu bağlamda çalışma kapsamında ikiz rakip üretiminin hangi cinste daha baskın olup olmadığını araştırmak amacıyla (özel sektörde, yarı özel - yarı kamu ve kamu kurumlarında) hem erkek hem kadın çalışanlara yönelik anket uygulanmış olup çıkan sonuçlardan kadının ikiz rakip üretiminde daha baskın olduğu görülmektedir.

Çalışma kapsamında hazırlanan 100 adet anket rastgele özel, yarı özel- yarı kamu ve kamu kurumlarında hem kadın hem erkek çalışanlara iletilmiş olup, gerek zamanın yetersiz oluşu gerek mobbing konusu ile ilgili araştırmaya katılım sağlamaya çekinilmesinden kaynaklı 10'u kamudan ve 7'si yarı özel- yarı kamu kuruluşlarında çalışanlar tarafından ankete katılım reddedilmiş; 17 anket geri iade edilmiştir. Bu sebeple sonuçlar, doldurulan 83 adet anket üzerinden analiz edilmiştir. Bu bağlamda ankette isim ve kurum belirtilmemesi gerektiği hususu ile bağıml değişkenleri içeren cinsiyet, eğitim vs. gibi bireysel sorularla birlikte bağımsız değişkenleri içeren mobbing ve ikiz rakip üretimine odaklı toplam 17 soru hazırlanmıştır. Çıkan sonuçların kısa bir özeti aşağıdaki şemalarda gösterilmektedir; 
Şekil 1: Cinsiyet Dağılımı

\begin{tabular}{|c|c|}
\hline \multicolumn{2}{|c|}{ Cinsiyet } \\
\hline Kadın & 32 \\
\hline Erkek & 51 \\
\hline Toplam & 83 \\
\hline
\end{tabular}

Anketin birinci sorusunda yer alan cinsiyet dağılımına göre, katılım sağlayanların 32'si kadın, 51'i erkektir.

\section{Şekil 2: Eğitim Dağılımı}

\begin{tabular}{|l|c|c|c|c|c|}
\hline Ĕ̆itim & İlköğretim & Lise & Lisans & Lisans üstü & Toplam \\
\hline Kadın & - & 6 & 19 & 7 & 32 \\
\hline Erkek & 4 & 9 & 32 & 6 & 51 \\
\hline
\end{tabular}

Anketin üçüncü sorusunda yer alan eğitim dağılımına göre, katılım sağlayan kadınların 6'sı lise, 19'u lisans, 7'si lisansüstü mezunuyken, erkeklerin 4'ü ilköğretim, 9'u lise, 32'si lisans, 6'sı lisansüstü mezunudur.

\section{Şekil 3: Çalışılan Kurum}

\begin{tabular}{|l|c|c|c|c|}
\hline Çalışılan Kurum & Özel Sektör & Yarı özel - Yarı Kamu & Kamu & Toplam \\
\hline Kadın & 12 & 13 & 7 & 32 \\
\hline Erkek & 20 & 19 & 12 & 51 \\
\hline
\end{tabular}

Anketin beşinci sorusunda yer alan çalışılan kurum bilgilerine göre, katılım sağlayan kadınların 12'si özel sektörden, 13'ü yarı özel- yarı kamu kuruluşlarından, 7’i ise kamu kurumlarında çalışmakta olup ankete katılım sağlayan erkeklerin 20’i özel sektörden, 19’u yarı özel- yarı kamu kuruluşlarından ve 12'i kamu kurumlarında çalışmaktadır.

\section{Şekil 4: Çalışılan Birim}

\begin{tabular}{|l|c|c|c|c|c|c|}
\hline \multirow{2}{*}{ Çalışılan Birim'de } & \multicolumn{2}{|c|}{ Özel Sektör } & \multicolumn{2}{c|}{ Yarı özel - Yarı Kamu } & \multicolumn{2}{c|}{ Kamu } \\
\cline { 2 - 7 } & $\begin{array}{c}\text { Kadın } \\
\text { Toplam } \\
12\end{array}$ & $\begin{array}{c}\text { Erkek } \\
\text { Toplam } \\
20\end{array}$ & $\begin{array}{c}\text { Kadın } \\
\text { Toplam } \\
13\end{array}$ & $\begin{array}{c}\text { Erkek } \\
\text { Toplam } \\
19\end{array}$ & $\begin{array}{c}\text { Kadın } \\
\text { Toplam } \\
7\end{array}$ & $\begin{array}{c}\text { Erkek } \\
\text { Toplam } \\
12\end{array}$ \\
\hline $\begin{array}{l}\text { Başlangıctan itibaren aynı } \\
\text { birimde çalışmaktayım. }\end{array}$ & 9 & 10 & 6 & 10 & 5 & 9 \\
\hline
\end{tabular}




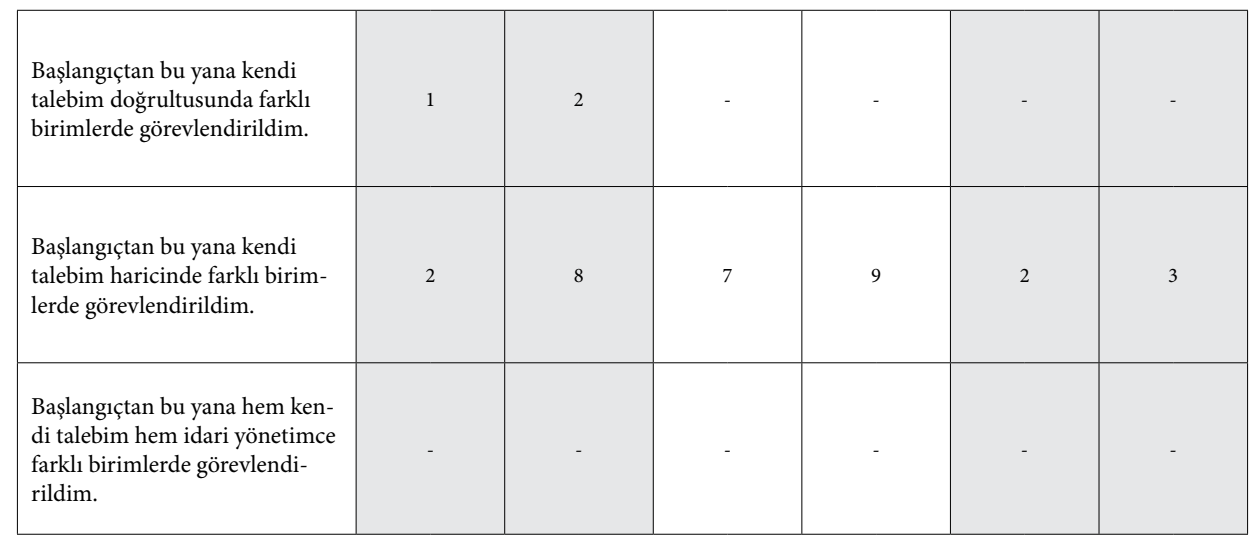

Anketin 7'nci sorusunda yer alan çalışılan birim ile ilgili olarak özel sektörden ankete katılım sağlayan 12 kadından 9'u kurum içinde çalıştığı kurumda işe başlangıcından itibaren aynı birimde çalışırken, 1'i başlangıçtan bu yana kendi talebi doğrultusunda farklı birimlerde, 2'si başlangıçtan bu yana kendi talebi haricinde farklı birimlerde görevlendirilmektedir. Yarı özel- yarı kamudan ankete katılan toplam 13 kadından 6's1 başlangıçtan itibaren aynı birimde, 7'si ise başlangıçtan bu yana kendi talebi haricinde farklı birimlerde görevlendirilmektedir. Kamu kuruluşlarından ankete katılan toplam 7 kadından 5'i başlangıçtan itibaren aynı birimde çalışmakta, 2'si ise başlangıçtan bu yana kendi talebi haricinde farklı birimlerde görevlendirilmektedir. Özel sektörden ankete katılım sağlayan 20 erkekten 10'u başlangıçtan itibaren aynı birimde, 2'si başlangıçtan bu yana kendi talebi doğrultusunda farklı birimlerde ve 8'i başlangıçtan bu yana kendi talebi haricinde farklı birimlerde görevlendirilmektedir. Yarı özel- yarı kamudan ankete katılan toplam 19 erkekten 10'u çalıştığı kurumda başlangıçtan itibaren aynı birimde çalışmakta, 9'u ise çalıştığın kurumda başlangıçtan bu yana kendi talebi haricinde farklı birimlerde görevlendirilmektedir. Kamu kuruluşlarından ankete katılan toplam 12 erkekten 9'u çalıştığı kurumda ise başladığı günden itibaren aynı birimde çalışmakta, 3’ü ise kendi talebi haricinde farklı birimlerde görevlendirilmektedir.

\section{Şekil 5: Mobbing Bilinirliği}

\begin{tabular}{|l|c|c|}
\hline & Kadın & Erkek \\
\hline Medya (Gazete, TV, Dergi, Radyo v.s.) & 27 & 33 \\
\hline Çalıştığım Kurumdan & 32 & 48 \\
\hline Soyal Medya & - & - \\
\hline Çevremden (Çevremden Duyduğum Olaylar) & 23 & 39 \\
\hline Diğer & - & - \\
\hline Kanunlardan & 5 & 24 \\
\hline Kendi Yaşadığım Olaylar & 19 & 28 \\
\hline
\end{tabular}

Anketin 9'ncu sorusunda ankete katılanlardan, çalışma yaşamında yönetim veya per- 
sonelden kaynaklı olumsuz olaylar yaşayan çalışanlar hakkında yukarıda sıralı maddelerden birden fazla işaretlemeleri istenmiştir. Soruda bilhassa mobbing kavramı belirtilmemiş olup çalışma yaşamında karşılaşılan bu tip olayların mobbing olarak algılanıp algılanmadığının farkındalığına da dikkat çekilmiştir. Sonuçlara göre toplam ankete katılım sağlayan 32 kadından 27'si bu tip olayları medyadan, 32'si çalıştığı kurumdan, 23'ü çevresinden, 5'i kanunlardan, 19'u ise kendi yaşadığı olaylardan bilmektedir. Ankete katılan toplam 51 erkekten ise 33'ü medyadan, 48'i çalıştığ kurumdan, 39 'u çevresinden, 24 'ü kanunlardan ve $28^{\prime}$ i ise kendi yaşadığı olaylardan ötürü mobbing bilinirliği bulunmaktadır.

\section{Şekil 6: a) Benzerlik ve Taklit Edilme ${ }^{7}$}

\begin{tabular}{|l|c|c|}
\hline & Kadın & Erkek \\
\hline Evet & 23 & 38 \\
\hline Hayır & 5 & 2 \\
\hline Muhtemel & 3 & 7 \\
\hline Bilemiyorum & 1 & 4 \\
\hline
\end{tabular}

Anketin 12. sorusunda yer alan "çalıştığınız kurumda size benzemek isteyen/isteyenler veya taklit eden/edenler var mı?" sorusu sorulmuştur. Ankete katılım sağlayan toplam 32 kadından 23'ü bu soruya evet, 5'i hayır, 3'ü muhtemel, 1'i ise bilemediğini işaretlerken, ankete katılan toplam 51 erkekten 38'i evet, 2'si hayır, 7'si muhtemel ve 4 'ü bilemediğini belirtmiştir.

\section{Şekil 7: b) Benzerlik ve Taklit Edilme}

\begin{tabular}{|l|c|c|}
\hline & Kadın & Erkek \\
\hline Mevkiinizden Kaynaklı & 6 & 21 \\
\hline İyi Eğitimli Oluşunuzdan Kaynaklı & 22 & 43 \\
\hline Çevreniz Tarafından Sevilen Biri Oluşunuzdan Kaynaklı & 26 & 35 \\
\hline Becerikli Oluşunuzdan Kaynaklı & 20 & 22 \\
\hline Üstleriniz Tarafından Takdir Edilmenizden Kaynaklı & 25 & 19 \\
\hline
\end{tabular}

Anketin 12. sorusuyla ilişkili alt soruda ankete katılanlardan kendilerine benzemek isteyenlerin veya taklit edenlerin neden veya nedenlerden kaynaklı olduğu sorulmuş olup birden fazla seçeneğin işaretlenebileceği belirtilmiştir. Buna göre, toplam $32 \mathrm{ka}$ dından 6'sı kendi mevkisinden kaynaklı, 22'si iyi eğitimli oluşundan kaynaklı, 26'sı çevresi tarafından sevilen biri oluşundan kaynaklı, 20'si becerikli oluşundan kaynaklı, 25 ’ ise üstleri tarafından takdir edildiğinden kaynaklı kendisinin benzerleri ve taklitleri olduğunu düşünmektedir. Erkeklerde ise 21’i mevkisinden kaynaklı, 43’ü iyi

7 Şekil 6, Şekil 7 ve Şekil 8 ankette yer alan 12. soru dahilinde olmasından kaynaklı, şema adlandırmalarında a, b, c şeklinde bağlantı kurulmuştur. 
eğitimli oluşundan kaynaklı, 35’i çevresi tarafından sevilen biri oluşundan kaynaklı, 22'si becerikli oluşundan kaynaklı ve 19'u ise üstleri tarafından takdir edildiğinden kaynaklı kendisinin benzerleri ve taklitleri olduğunu düşünmektedir.

Şekil 8: c) Benzerlik ve Taklit Edilme

\begin{tabular}{|l|c|c|}
\hline & Kadın & Erkek \\
\hline Kendi Cinsim ve Aynı Statüdeki Personel & 15 & 18 \\
\hline Kendi Cinsim ve Üst Statüdeki Personel & 7 & 17 \\
\hline Kendi Cinsim ve Alt Statüdeki Personel & - & 10 \\
\hline Aynı Statüdeki ve Karşı Cinsim Personel & 1 & - \\
\hline Üst Statüdeki ve Karşı Cinsim Personel & 3 & - \\
\hline Alt Statüdeki ve Karşı Cinsim Personel & - & - \\
\hline
\end{tabular}

Anketin 12. sorusuyla ilişkili diğer bir alt soruda ankete katılanlara benzemek ve kendilerini taklit edenlere pozitif cevap verenlerden bu kişi veya kişilerin hangi statüden ve hangi cinsten olduğu işaretlenmesi istenmiştir. Soruya pozitif cevap veren $26 \mathrm{ka}$ dından kendisine benzemek isteyeni ve taklit edenin 15'i kendi cinsi ve aynı statüdeki personel, 7'si kendi cinsi ve üst statüdeki personel, 1'i aynı statüdeki ve karşı cins personel, 3’ü ise üst statüdeki ve karşı cins personel olduğunu düşünmektedir. Soruya pozitif cevap veren 45 erkekten kendisine benzemek isteyeni ve taklit edenin 18'i kendi cinsi ve aynı statüdeki personel, 17'si kendi cinsi ve üst statüdeki personel, 10'u kendi cinsi ve alt statüdeki personel olduğunu ve kendilerine benzemek isteyen veya taklit eden karşı cinsten personelin olmadığını düşünmektedir.

Şekil 9: Taklit Et Teşviği (ankete katılanlara olan teşvik)

\begin{tabular}{|l|c|c|}
\hline & Kadın & Erkek \\
\hline Evet & 11 & 3 \\
\hline Hayır & 19 & 35 \\
\hline Hatırlamiyorum & 2 & 7 \\
\hline
\end{tabular}

Anketin 13. sorusunda ankete katılanlara, çalıştıkları kurumda üstlerinin kendilerine $\mathrm{x}$ kişi gibi ol, onu taklit et diyerek teşvik verip vermedikleri sorulmuştur. Toplam 32 kadından 11'i evet, 19'u hayır ve 2'si hatırlamadıklarını işaretlerken, toplam 51 erkekten 3'ü evet, 35’i hayır ve 7’si hatırlamadığını belirtmiştir.

Şekil 10: Taklit Et Teşviği (ankete katılanların yaptığı teşvik)

\begin{tabular}{|l|c|c|}
\hline & Kadın & Erkek \\
\hline Evet & 30 & 45 \\
\hline Hayır & 2 & 6 \\
\hline
\end{tabular}


Anketin 14. sorusunda 13. sorunun tersi olarak kendilerinin astı olan birinden memnun olmadiklarında veya sevmediklerinde, sevdikleri bir personeli onun yerine geçirmek amacıyla teşvik ettiklerinin olup olmadığı veya böyle bir durumda ve amaçla sevdikleri personeli teşvik etmek isteyip etmedikleri sorulmuştur. Buna göre toplam 32 kadından 30'u evet, 2'si hayır, toplam erkeklerden 45’i evet, 6'sı hayır demiştir.

\section{Şekil 11: Görev Devri}

\begin{tabular}{|l|c|c|}
\hline & Kadın & Erkek \\
\hline Evet & 18 & 16 \\
\hline Hayır & 14 & 35 \\
\hline
\end{tabular}

Anketin 15. sorusunda ankete katılanlara “üstlerinizin veya aynı statüdeki arkadaşlarınızın yönlendirmesi ile bir başka personeli örnek alarak onun görevlerini üstlendiğiniz oldu mu?” sorusu sorulmuştur. Toplam 32 kadından 18'i evet, 14'ü hayır derken toplam 51 erkekten 16 'sı evet, 35'i ise hayır demiştir.

\section{Şekil 12: Rakip Gösterme}

\begin{tabular}{|l|c|c|}
\hline & Kadın & Erkek \\
\hline Evet & 15 & 28 \\
\hline Hayır & 7 & 9 \\
\hline Olabilir, Bazen Böyle Hissediyorum & 10 & 14 \\
\hline
\end{tabular}

Anketin 16. sorusunda katılımcılara çalıştıkları kurumda kendilerine karşı bir rakip gösterilip gösterilmediği sorulmuştur. Toplam 32 kadından 15'i evet, 7'si hayır ve 10’u ise emin olmamakla birlikte olabilirliğini düşünmektedir. Toplam 51 erkekten ise 28'ievet, 9’u hayır ve 14'ü emin olmamakla birlikte rakiplerinin olabilirliğini düşünmektedir.

\section{Şekil 13: a) İstenmeyen Personel ${ }^{8}$}

\begin{tabular}{|l|c|c|}
\hline & Kadın & Erkek \\
\hline Evet & 26 & 42 \\
\hline Hayır & 6 & 9 \\
\hline
\end{tabular}

Anketin 17. sorusunda katılımcılara "çalıştığınız kurumda aynı birimde/ şubede/ koordinatörlükte çalışmak istemedikleri personel var mı” sorusu sorulmuştur. Toplam 32 kadından 26'sı evet, 6'sı hayır derken, toplam 51 erkekten 42'si evet, 9'u hayır demiştir.

8 Şekil 13 ve Şekil 14 ankette yer alan 17. soru dahilinde olmasından kaynaklı, şema adlandırmalarında a, b şeklinde bağlantı kurulmuştur. 


\section{Şekil 14: b) İstenmeyen Personel}

\begin{tabular}{|l|c|c|}
\hline & Kadın & Erkek \\
\hline Çalı̧̧mak İstemediğim Personelin Yerini Almak İsterim & 5 & 8 \\
\hline $\begin{array}{l}\text { Çalışmak İstemediğim Personelin Yerine Tercih Ettiğim Personeli } \\
\text { İsterim }\end{array}$ & 21 & 28 \\
\hline $\begin{array}{l}\text { Çalışmak İstemediğim Personel Yeter ki Gitsin Yerine Kim Gelirse } \\
\text { Gelsin }\end{array}$ & - & 6 \\
\hline
\end{tabular}

Anketin 17. sorusunun şıkkında birlikte çalışmak istemedikleri personel yerine yukarıda yer alan üç seçenekten birini seçmeleri istenmiştir. Buna göre, çalıştıkları kurumda aynı birimde/şubede/ koordinatörlükte çalışmak istemedikleri personelin var olup olmadığ 1 sorusuna evet diyen toplam 26 kadından 5 'i çalışmak istemediği personelin yerini almak istediğini, 21'inin ise çalışmak istemediği personelin yerine tercih ettiği personeli istediğini belirtmektedir. Erkek katılımcılarda ise; çalıştıkları kurumda aynı birimde/şubede/ koordinatörlükte çalışmak istemedikleri personelin var olup olmadığ sorusuna evet diyen toplam 42 erkekten 8 'i çalışmak istemediği personelin yerini almak istediğini, 28 'inin ise çalışmak istemediği personelin yerine tercih ettiği personeli istediğini, 6'sının ise yeter ki istemedikleri personelin gitmesini yerine kimin geleceğini umursamadıklarını belirtmektedir.

\section{Sonuç}

Kapitalist sistem içerisinde kadının hem ev yaşamı hem de çalışma yaşamında birçok mücadele ile başa çıkmaya çalıştığı açık bir gerçektir. Bu çalışma ise kadının mevcut iş yüküne ek olarak çalışma yaşamında karşılaştığı mobbinge dikkat çekerek, ikiz rakip üretimini açıklamayı amaç edinmiştir. Toplumumuzda kadın nüfusun fazla ama çalışma yaşamında azınlıkta olduğu göz önünde bulundurulduğunda, kadının hem cinsinden darbe yemesi yıkıcı bir etki oluşturmaktadır. Günümüzde kadın haklarına ve dayanışmaya önem veren ve bunu amaç edinen birçok ulusal ve uluslararası dernek ve kuruluşun artmasına karşın çalışma yaşamında halen kadının kadına destek olmak yerine rakip ve düşman olma durumu mevcudiyetini korumaktadır. Gerek aile yaşamında gerek çalışma yaşamında kadının fikirlerini ve çalışmalarını hem cinsi ile paylaşmak isteyişi son derece doğal iken bu durumun kendi aleyhine döndürülerek kadının kadın tarafından ezilmesi, kadınların hem cinslerine olan güvenini sekteye uğratmaktadır.

Mobbing kavramı görüldüğü üzere hem kadını hem erkeği kapsamakla birlikte çalışma yaşamında kişiyi bunalıma sokmakta ve aile yaşantısını olumsuz yönde etkilemektedir. Mobbing ile ilgili mağdurun ne şekilde etkilendiği araştırılırken failin zaman, koşul ve bireylerle bağlantılı dinamik süreçler çerçevesinde şimdiye kadar nasıl 
bir mobbing çeşidi uygulandığı hususuna ağırlık verilememiştir. Bu sebeple mobbing failinin uyguladığı bir sürece açıklık getiren ikiz rakip üretimi kavramı bu çalışmanın önemli bir katkısını oluşturmaktadır. Çalışmada gözlem tekniği ile birlikte kavrama açıklık getirilerek çalışmanın hipotezi doğrultusunda anket çalışması yapılmıştır. Mobbing ile birlikte ikiz rakip üretiminde kadının mı yoksa erkeğin mi daha baskın olduğu araştırılmış olup;

I. Kadının erkeğe oranla daha fazla ikiz rakip üretimini gerçekleştirdiği,

II. İkiz rakip üretiminin en çok yatay ve üstün asta yaptığı mobbing içerisinde gerçekleştiği, kıdemli çalışanların kuruma dahil olan yeni çalışanlar üzerinde daha çok ikiz rakip üretimini uyguladığı,

III. Mobbing mağdurlarının mevcut durumlarını korumak diğer bir ifadeyle işten ayrılıp düzenlerini bozmamak amacıyla yapılan mobbinge ses çıkarmadıkları sonuçlarına varılmıştır.

Çalışma kapsamında yapılan anket, sadece pilot bir analizi oluşturmakla beraber sonraki akademik çalışmalar ve istatistiki analizler için de örnek teşkil etmektedir. $\mathrm{Bu}$ çalışmada anket ile ilgili olarak katılımcıların istekli olmadıkları, kurum yönetimiyle problem yaşama ve işini kaybetme korkularına sahip oldukları ve cam tavan sendromunu tecrübe ettikleri tespit edilmiş; bu sebeplerden ötürü benzer çalışmaların araştırmaya katılanlara verilecek devlet güvencesiyle desteklenmesinin önemine dikkat çekilmiştir.

İkiz rakip üretiminde kadının kadına olan engelini aşmak amacıyla kurum ve kuruluşlarda kadın birliklerinin sadece çoğalarak kurum dişı faaliyetlerde etkin olması değil aynı zamanda kurumun kendi iç işleyişinde düzenlemelerin yapılıyor olması gerekmektedir. Bu hususta mobbing araştırmalarının yapılması büyük önem taşımakla beraber, mevcut sorunlara çözüm üreterek hem çalışma yaşamında hem de etkisi olduğu ev yaşamında refahın sağlanması amaç edinilmelidir. Aksi takdirde kadının aile yapısındaki önemli etkisi ve sorumluluklarına ek olarak iş yerindeki dışlanmalara maruz kalması daha fazla yıpratıcı olmakta; bu da sosyal yaşantıdaki dayanışmanın bozulmasına neden olmaktadır. Bu bağlamda çözümler üretmek amacıyla kurum ve kuruluşlarda, bağımsız mobbing birimleri oluşturulabilir veya devlet güvencesiyle kurum ve kuruluşlar denetime tabi tutulabilir, devlet teşviği kapsamında kurumlarda mobbing hususuna dikkat çekilerek örgütsel iş ortamının sağlığı ve verimliliğini arttırıcı önlemler almaları sağlanabilir, kadının kadına sosyal yaşantısı dışında iş yaşamında da destek vermesine yönelik farkındalık oluşturucu çalışmalar yapılabilir. Bu sayede olası mobbing saldırılarına karşı hem iş verimliliği hem de etkisi olduğu ev yaşantısı korunabilir. 


\section{Kaynakça}

Archer, D. (1999). "ExploringBullyingCulture in the Para-MilitaryOrganization", International Journal of Manpover, 20(1/2), s. 94-105.

Berber, M. ve E, B. Y. (2008). “Türkiye’de Kadın İstihdamı: Ülke ve Bölge Düzeyinde Sektörel Analiz", Işs, Güç Endüstri İlişkileri ve İnsan Kaynakları Dergisi, 10(2), s. 1-16.

Davenport, N. , Schwartz, R. D. , Elliott, G. P. (2003). Mobbing: İşyerlerinde Duygusal Taciz, (Çev: Osman Cem Önortay), Sistem Yayıncılık: İstanbul.

DiMartino, V. , Hoel, H. , Cooper, C. C. (2003). "Preventing Violence and Harrassment in the Workplace", European Foundation for the Improvement of Living and Working Conditions,

http:/www. eurofound. eu. int/publications/files/EFO2109EN, pdf (ET:15. 02. 2017).

Dural, F. Z. (2016). Mobbing, İstanbul Büyükşehir Belediyesi Sağlık Daire Başkanlığı Sağlık ve Hıfzıssıhha Müdürlüğü Kadın ve Aile Sağlığını Koruma Hizmetleri Eğitim Birimi, http://docplayer. biz. tr/20364974-Mobbing-psikolog-fatma-zehra-dural-ibb-saglik-daire-baskanligi-saglik-ve-hifzissihha-mudurlugu-kadin-ve-aile-sagligini-koruma-hizmetleri. html (ET: 15. 02. 2017).

Einersen, S. , Hoel, H. , Zapf, D. , \& Cooper, C. L. (2003). Bullying and Emotional Abuse in The Workplace: International Perspectives in Research and Practice, London: Taylor\& Francis Books Ltd. , s:4-15.

Espresso, (2000). www. espressonline. it (ET: 01. 02. 2017)

Field, T. (2002). “There's No Accounting for Bullying”, British Medical Journal, e-Letters, s. 324-342.

Hoel, H. , Cooper, C. (2000). "Destructive Conflict and Bullying at Work" Sponsored by the British Occupational Science and Technology (UMIST),

http://www. csren. gov. uk /UMISTreportHelgeHoel1. PDF (ET: 15. 02. 2017).

Kök, S. B. (2006). "İş Yaşamında Psikolojik Şiddet Sarmalı Olarak Yıldırma Olgusu ve Nedenleri”, Selçuk Üniversitesi Sosyal Bilimler Enstitüsü Dergisi, 16, s. 436-438.

Leymann, H. (1996). “The Content and Development of Mobbing at Work”, European Journal of Work and Organizational Psychology, 5(2), s. 165-184.

MFA, (2017). "Kadın Hakları Alanında Gelişmeler”,

http://www. mfa. gov. tr/turkiye_de-kadin-haklari-alaninda-kaydedilen-gelismeler. tr. mfa

(ET: 12. 02. 2017)

NTV Haber, (2013). “Türkiye’nin Mobbing Karnesi”, http://www. ntv. com. tr/ekonomi/turkiyenin-mobbing-karnesi, 8B9nQH_8zkKZbbhjfUI0Ag (ET:12. 02. 2017).

Tinaz, P. (2006). Issyerinde Psikolojik Taciz (Mobbing), İstanbul: Beta Basım Yayım.

Türkiye İstatistik Kurumu, (2016). "İstatistiklerle Kadın”, file://C:/Users/elmsahoz/Downloads/\%C4\%B0statistiklerle_Kad\%C4\%B1n_07. 03. 2016\%20(1). pdf(ET: 13. 02. 2017).

WHO. (2003). “Occupational and Environmental Health Programme, Raising Awareness of Pyschological Harrassment at Work”, Protecting Worker's Health Series, N. 4.

Yücetürk, E. (2002). “Bilgi Çağında Örgütlerin Görünmeyen Yüzü: Mobbing”, http://bilgiyonetimi. org/cm/paper/yaz. ark. php (ET:12. 02. 2017).

Zapf, D. (1999). “Organizational, Work, Group Related and Personal Causes of Mobbing/ 
Bullying at Work", International JournalManpower, 20(1/2), s. 70-85.

http://www.psychologicalharassment.com/Professor-Heinz-Leymann-Biography.htm (ET:12. 02. 2017).

http://www. csgb. gov. tr/media/3417/proje_2015. pdf (ET: 13. 02. 2017).

http://ec.europa.eu/justice/grants/results/daphne-toolkit/en/content/mobbing-i-raising-awareness-women-victims-exchange-good-practices (ET: 14. 02. 2017).

http://www. psychologicalharassment. com/bullying-vs-mobbing. htm (ET: 14. 02. 2017). 


\section{Ek: Çalışmada Yer Alan Anket Soruları}

\section{Cinsiyetiniz?}

$\square$ Kadin $\square$ Erkek

\section{Yașınız}
18-25
$\square 25-37$
$37-50$
50 ve üzeri

\section{Eğitiminiz}

$\square$ İlköğretim $\square$ Lise Lisans $\square$ Lisans üstü

\section{4. Çalışma Şekli}

$\square$ Tam zamanlı $\square$ Yarı zamanlı $\square$ Saat ücretli

\section{5. Çalıştığınız Kurum}

$\square$ Özel sektör $\square$ Kamu $\quad \square$ Yarı kamu yarı özel $\square$ Kendi işyeri

*Diğer

*Çalıştığınız kurum “diğer” ise lütfen belirtiniz.

6. Çalıştığınız kurumda kaç yıldan beri çalışmaktasınız?

$\square$ 1 Seneden az $\square$ 1 Sene $\square$ 1-3 Sene $\square$ 3-5 Sene
$\square$ 5-7 Sene $\quad \square$ 7-10 Sene $\square$ 10 ve Üzeri

\section{7. Çalıştığınız kurumda;}

Başlangıçtan itibaren aynı birimde çalışmaktayım.

$\square$ Başlangıçtan bu yana kendi talebim doğrultusunda farklı birimlerde görevlendirildim.

Başlangıçtan bu yana kendi talebim haricinde farklı birimlerde görevlendirildim.

$\square$ Başlangıçtan bu yana hem kendi talebim hem idari yönetimce farklı birimlerde görevlendirildim. 


\section{Aşağıdaki maddelerden işaretlediklerim hakkında bilgim var;}

Çalıştığım kurum hakkında yönetmeliği biliyorum.
Sadece haberdarım
Az çok biliyorum
Hepsini biliyorum

$\square$ İş ve Çalışma Hukuku'nu ve haklarımı biliyorum.
Sadece haberdarım
Az çok biliyorum
Hepsini biliyorum

9. Çalışma yaşamında yönetim veya personelden kaynaklı olumsuz olaylar yaşayan çalışanlar hakkında aşağıda işaretlediğim * madde/maddelerden dolayı bilgim mevcut;

${ }^{*}$ Birden fazla madde işaretleyebilirsiniz.

$\square$ Medya (gazete, tv, dergi, radyo vs. )

$\square$ Çalıştı̆̆ım kurumdan

Sosyal Medya

$\square$ Çevremden (çevremden duyduğum olaylar)

$\square *$ Diğer

$\square$ Kanunlardan

$\square$ Kendi yaşadı̆̆ım olaylar

9a. *Seçtiğiniz madde veya maddeler içerisinde “diğer” var ise lütfen kısaca ne olduğunu belirtiniz.

9b. * Seçtiğiniz madde veya maddeler içerisinde "kendi yaşadığım olaylar" var ise lütfen ne tarz olay/olaylar olduğunu kısaca belirtiniz. 
10. Çalışma yaşamımda olumsuz olay yaşadığımda ve haksızlığa uğradığımda aşağıda işaretlediğim madde/maddeleri uygularım;

$\square$ Önce sabrederim sonra hakkımı aramaya çalışırım.

$\square$ Hakkımı aramak istesem de olumsuzluğu ve haksızlığı yaratanlar güçlü olduğu için bir işlem yapmam mevcut düzenimi bozmamak için sabrederim.

$\square$ Kurumun üst yönetimi ile irtibata geçerim.

$\square$ Hukuki yola başvururum.

$\square$ İşten ayrılırım.

11. Çalışma yaşamınız boyunca çalıştığınız kurumun yönetimi veya kurumda çalışan personeller tarafından haksızlığa uğradığınızı düşünüyor musunuz?

$\square$ *Evet

$\square$ Hayır

$\square *$ Emin değilim

*Cevabınız “evet” veya “emin değilim” ise aşağıdaki madde/maddeleri işaretleyiniz;

Bedensel taciz (şiddet, karşı cinsin uygunsuz hareketleri vs)

Sözlü taciz (küfür, hakaret, karşı cinsin uygunsuz sözleri vs)

Hakkımda asılsız dedikodu çıkarılması

Birden bire birimimin/şubemin/koordinatörlüğümün değiştirilmesi

Aynı birim/şube/koordinatörlükte eş değerimdeki personellere göre bana daha fazla iş yükü verilmesi

Çalışmalarımı yaptığım halde yetersiz olmakla suçlanmam

Kapasitemden daha hafif işlerle oyalanmam

$\bigcirc$ İlerlemenize engel olacak taklitlerinizin oluşturulması (örneğin siz bir çalışma yapıyorken farklı bir personele o görevi öğretmenizin istenmesi ve o görevi o personele devredilmesi vb. )

Yalnızlaştırılma

Maaşınızdan kesilme 
12. Çalıştığınız kurumda size benzemek isteyen/isteyenler veya taklit eden/edenler var mi?

$\square *$ Evet

$\square$ Hayır

$\square *$ Muhtemel

Bilemiyorum

12a. *Cevabınız “evet”, “muhtemel”, “bilemiyorum” ise sizce aşağıdaki madde/maddelerden hangi sebeplerden size benzemek istediklerini düşünüyorsunuz?

Mevkiinizden kaynaklı

$\bigcirc$ İyi eğitimli oluşunuzdan kaynaklı

Çevreniz tarafından sevilen biri oluşunuzdan kaynaklı

Becerikli oluşunuzdan kaynaklı

Üstleriniz tarafından takdir edilmenizden kaynaklı

12b. *Cevabınız “evet”, “muhtemel”, “bilemiyorum” ise sizce aşağıdaki madde/maddelerden kimin/kimlerin size benzemek istediğini düşünüyorsunuz?

Kendi cinsim ve aynı statüdeki personel

Kendi cinsim ve üst statüdeki personel

Kendi cinsim ve alt statüdeki personel

Aynı statüdeki ve karşı cinsim personel

Üst statüdeki ve karşı cinsim personel

Alt statüdeki ve karşı cinsim personel

13. Çalıştığınız kurumda sizin üstünüz, $x$ kişi gibi ol onu taklit et dediği oldu mu?

Evet

Hayır

Hatırlamiyorum 
14. Siz, altınızda çalışan personellerinizden birinden memnun olmadığınızda veya sevmediğinizde sevdiğiniz bir personelinizi onun yerine geçirmek amacıyla teşvik ettiğiniz oldu mu veya böyle bir durumda ve amaçla sevdiğiniz personeli teşvik edip destek verir misiniz?

\section{Evet \\ Hayır}

15. Siz, üstünüzün veya aynı statüdeki arkadaşlarınızın yönlendirmesi ile bir başka personeli örnek alarak onun görevlerini üstlendiğiniz oldu mu?

\section{Evet \\ Hayır}

16. Çalıştığınız kurumda size karşı bir rakip gösteriliyor mu?

$\square$ Evet

$\square$ Hayır

$\square$ Olabilir, bazen böyle hissediyorum

17. Çalıştığınız kurumda aynı birimde/şubede/koordinatörlülkte çalışmak istemediğiniz personel var $\mathrm{mı}$ ?

*Evet

Hayır

*Cevabınız “evet” ise aşağıdakilerden hangisinin olmasını istersiniz?

Çalışmak istemediğim personelin yerini almak isterim.

Çalışmak istemediğim personelin yerine tercih ettiğim personeli isterim.

Çalışmak istemediğim personel yeter ki gitsin yerine kim gelirse gelsin. 
KADEM Kadın Araştırmaları Dergisi 